\title{
Edward Urbańczyk*
}

Instytut Ekonomii

Uniwersytet Szczeciński

Magdalena Suska-Szczerbicka**

Instytut Ekonomii

Uniwersytet Szczeciński

\section{ANALIZA KORZYŚCI EKOLOGICZNYCH POLSKIEJ ENERGETYKI WIATROWEJ}

\begin{abstract}
Streszczenie
W artykule przedstawiono korzyści ekologiczne wynikające z wdrażania energii elektrycznej z elektrowni wiatrowych. Podkreślono powiązania między energetyką odnawialną a problemem ochrony środowiska i rynkiem energii elektrycznej. Przedstawiono rozmiary produkcji energii konwencjonalnej i odnawialnej w Polsce w latach 2005-2016. Ukazano wpływ sektora energetycznego na środowisko i zdrowie ludzi. Z analizy wynika, że energetyka wiatrowa to niezbędne źródło energii elektrycznej, które pozwala uniknąć wielomilionowych kosztów zewnętrznych.
\end{abstract}

Słowa kluczowe: energetyka zawodowa, wiatrowa, korzyści ekologiczne

\section{Wprowadzenie}

Produkcja energii i jej wykorzystywanie wpływają na poprawę poziomu życia, jednocześnie powodując degradację i niszczenie środowiska naturalnego. Pogodzenie

* Adres e-mail: edwaru@o2.pl.

** Adres e-mail: biuro@am-wind.pl. 
tych dwóch sprzeczności możliwe staje się tylko wtedy, gdy zostaną podjęte kompleksowe działania zmierzające do podwyższenia efektywności wykorzystania energii, zastępowanie węgla rozwiązaniami mniej zagrażającymi środowisku. Sektor energetyczny związany jest z wieloma negatywnymi oddziaływaniami na środowisko, wśród nich głównymi są: zanieczyszczenie powietrza atmosferycznego, gleby, wód powierzchniowych, a także globalne zmiany klimatu, które również mają dalsze negatywne skutki. Emisja zanieczyszczeń wywołuje niekorzystne zmiany i mierzalne skutki ekonomiczne. Te niekorzystne efekty mogą zostać oszacowane, jednak nie mają odzwierciedlenia w cenie energii elektrycznej wprowadzanej na rynek. Obciążenie nimi sprawców zwiększa świadomość na temat negatywnego oddziaływania stosowanych technologii w energetyce i ułatwia podejmowanie decyzji dotyczących unowocześnienia stosowanych technologii, jak również wywołuje działania zapobiegawcze i daje przekonanie o wynikających z tego korzyściach. Szacowanie kosztów zewnętrznych dla podejmowania decyzji strategicznych wciąż jest wyzwaniem dla naukowców. Teoria pokazuje, że w zakresie kosztów powinno uwzględniać się nie tylko koszty realizacji i eksploatacji, ale i społeczne skutki negatywnego oddziaływania na człowieka i środowisko. Celem artykułu jest przedstawienie korzyści ekologicznych wynikających z funkcjonowania energetyki wiatrowej i wykazanie efektu ekologicznego. By wyznaczyć efekt ekologiczny elektrowni wiatrowych, odniesiono się do energii elektrycznej produkowanej z węgla, wyznaczając tym samym wysokość strat ekologicznych spowodowanych spalaniem węgla. Wycena tych strat jest podstawą do przygotowania wyceny efektu ekologicznego w sytuacji zastąpienia energii z węgla energią z wiatru. Szkody ekologiczne powstałe w związku $\mathrm{z}$ energią konwencjonalną utożsamia się z kosztami zewnętrznymi obciążającymi podmiot wytwarzający energię.

\section{Wycena kosztów zewnętrznych}

Zastosowana metoda wyceny monetarnej kosztów zewnętrznych ma na celu zaprezentowanie ujęcia ilościowego niekorzystnych efektów zewnętrznych działania energetyki konwencjonalnej, tj. efektów zewnętrznych powodowanych przez emisję zanieczyszczeń gazowych pochodzących ze spalania paliw kopalnianych. Podczas procesu produkcji energii elektrycznej elektrownie wprowadzają zanieczyszczenia wywołujące negatywne skutki uboczne, które dalej generują efekty ekonomiczne. 
Obliczenie tych efektów w wartości pieniężnej wciąż jest kontrowersyjne. Najczęściej wykorzystywana metoda dla systemów elektroenergetycznych to szacunek wielkości kosztów zewnętrznych. Obecnie za najbardziej rozwiniętą metodykę klasyfikowania kosztów zewnętrznych uznaje się metodykę „ścieżki oddziaływań”, która rozwinęła się w projekcie Komisji Europejskiej ExterneE ${ }^{1}$ i następnie Ne$\mathrm{wExt}^{2}$, ExterneE-Pol ${ }^{3}, \mathrm{NEEDS}^{4}{ }^{\mathrm{i}} \mathrm{CASES}^{5}$. Koszty zewnętrzne wynikające z energetyki zawodowej obejmują wszystkie negatywne skutki związane z technologią wytwarzania energii elektrycznej i cieplnej na poszczególnych etapach procesu technicznego związanego z produkcją energii czy ciepła. Etapy procesu technicznego obejmują budowę elektrowni, wydobycie i transport surowców energetycznych, emisję zanieczyszczeń wytwarzanych podczas produkcji energii oraz zamknięcie elektrowni. Wytwarzanie energii ze źródeł odnawialnych również wykazuje emisję zanieczyszczeń i związane z tym koszty zewnętrzne. W przypadku elektrowni wiatrowych koszty zewnętrzne dotyczą etapu produkcji maszyn i realizacji budowy, ale eksploatacja turbin wiatrowych nie powoduje emisji szkodliwych zanieczyszczeń. Koszty zewnętrzne powstałe $\mathrm{z}$ emisji zanieczyszczeń szacowane są dla kategorii oddziaływań takich jak: zdrowie ludzi, szkody w zbiorach rolnych, szkody materiałowe, bioróżnorodności i zmiany sposobu użytkowania ziemi. Metoda ta była wielokrotnie wykorzystywana w analizach kosztów i korzyści podejmowanych decyzji w propozycjach dyrektyw Komisji Europejskiej, przede wszystkim w programie Externe w zakresie jakości powietrza atmosferycznego, emisji zanieczyszczeń dla krajów członkowskich Unii Europejskiej. Jej obszar wciąż jest rozszerzany ${ }^{6}$. Autorzy prac naukowych z Ameryki i Europy opracowali analizy statystyczne wysokości kosztów zewnętrznych dla różnych technologii wytwarzania energii elektrycznej na podstawie 32 badań z 17 lat (Sundqvist, Sodernholm, 2003, s. 14-18). Badania wykonywano głównie na zlecenia agencji rządowych.

External Costs of Energy (ExterneE, 2003, s. 8).

2 New Elements for the Assessment of External Costs from Energy Technologies.

3 Externalities of Energy: Extension of Accounting Framework and Policy Applications.

4 New Energy Externalities Developments for Sustainability.

5 Costs Assessment of Sustainable Energy Systems.

${ }^{6}$ Raporty w ramach projektu dostępne są na oficjalnej stronie ExternE: www.externe.info. 
Tabela 1. Wartości kosztów zewnętrznych pochodzących ze spalania paliw stałych w elektroenergetyce w krajach Europejskich (euro/Mg)

\begin{tabular}{|l|c|c|c|}
\hline \multicolumn{1}{|c|}{ Kraj } & $\mathrm{SO}_{2}$ & NOx & Pył \\
\hline Austria & 9000 & $9000-16800$ & 16800 \\
\hline Belgia & $11388-12141$ & $11536-12296$ & $24536-24537$ \\
\hline Dania & $2990-4216$ & $3280-4728$ & $3390-6666$ \\
\hline Finlandia & $1027-1486$ & $852-1388$ & $1340-2611$ \\
\hline Francja & $7500-15300$ & $10800-18000$ & $6100-57000$ \\
\hline Niemcy & $1800-13688$ & $10945-15100$ & $19500-23415$ \\
\hline Grecja & $1978-7832$ & $1240-7798$ & $2014-8178$ \\
\hline Irlandia & $2800-5300$ & $2750-3000$ & $2800-5415$ \\
\hline Włochy & $5700-12000$ & $4600-13567$ & $5700-20700$ \\
\hline Holandia & $6205-7581$ & $5480-6085$ & $15006-16830$ \\
\hline Portugalia & $4960-5424$ & $5975-6562$ & $5565-6955$ \\
\hline Hiszpania & $4219-9583$ & $4651-12056$ & $4418-20250$ \\
\hline Średnie wartości wg Krewitta dla: & 3800 & 5500 & bd \\
\hline Hiszpania & 4100 & 7300 & bd \\
\hline Włochy & 1500 & 4300 & bd \\
\hline Szwecja & 6000 & 5000 & 13000 \\
\hline Unia Europejska (15) & \multicolumn{3}{|l}{} \\
\hline
\end{tabular}

Źródło: opracowanie własne na podstawie Kudełko, 2003.

Badania wykazują, że w krajach najbogatszych jednostkowe koszty zewnętrzne są najwyższe. Wysokie zaludnienie generuje wysokie koszty zewnętrzne. Najwyższe wartości odnotowały takie kraje, jak Niemcy, Belgia, Francja i Holandia. Wynik wysokich kosztów jest efektem niekorzystnych efektów zdrowotnych związanych ze sporym zaludnieniem w tych krajach. Kraje, które wykazują niższe stawki kosztów zewnętrznych to Irlandia, Portugalia i Hiszpania. Najniższe koszty zewnętrzne wykazują Szwecja i Finlandia, a także Grecja, w krajach tych jest niższe zaludnienie i mały efekt zdrowotny. Kraje wykazujące wysokie koszty zdrowotne cechuje także duża dbałość o środowisko; jako kraje rozwinięte stosują najlepsze technologie redukujące emisje, co dowodzi, że wdrażanie drogich technologii służących ograniczeniu emisyjności jest opłacalne. Nowoczesne technologie z punktu widzenia społecznego są zatem racjonalne i efektywne.

Badania strat ekologicznych w Polsce rozpoczęto w latach osiemdziesiątych, jednak dopiero w 2001 roku opublikowano pierwsze syntezy (Famielec, 2001) przeprowadzonych szacunków strat ekologicznych w sektorach gospodarki. Dotyczyły 
one przemysłu, rolnictwa, leśnictwa i gospodarki wodnej. Badania prowadzone dla polskiego systemu energetycznego wykonano za pomocą narzędzi zagranicznych badaczy. Badania prowadzone w ramach V Projektu ramowego Programu Unii Europejskiej zwanego ExternE-Pol (Dones, Heck, Bauer, Hirschberg, Bickel, Preiss, 2005), projektu NEEDS i CASES, z pomocą modelu komputerowego EcoSenseWeb usystematyzowały koszty zewnętrzne na tonę emitowanego zanieczyszczenia powietrza dla polskich elektrowni. W badaniach uwzględniono koszty zdrowotne, koszty emisji wpływające na uprawy rolne, na materiały budowlane, jak również koszty dotyczące uszczerbku różnorodności gatunków na niezagospodarowanych obszarach. Prezentowane dane są wartościami średnimi oszacowanymi z uwzględnieniem rozkładu źródeł emisji w Polsce. Średnie koszty zewnętrzne na jednostkę emisji zanieczyszczeń krajowego sektora energetycznego prezentuje tabela 2.

Tabela 2. Uśrednione koszty zewnętrzne emisji zanieczyszczeń powietrza dla krajowych elektrowni cieplnych [€/tonę zanieczyszczenia]

\begin{tabular}{|l|c|c|c|c|c|c|}
\hline & $\mathrm{SO}_{2}$ & NOx & PM 2.5-10 & PM 2.5 & NMVOC & $\mathrm{CO}_{2}$ \\
\hline zdrowie ludzi & 7232 & 4287 & 667 & 16331 & 499 & \\
\hline biosystem & -36 & 1173 & 0 & 0 & -59 & \\
\hline uprawy rolnicze & -8 & 155 & 0 & 0 & 126 & \\
\hline materiały budowlane & 579 & 145 & 0 & 0 & 0 & \\
\hline efekt cieplarniany & & & & & & 21 \\
\hline łącznie & 7767 & 5760 & 667 & 16331 & 566 & 21 \\
\hline
\end{tabular}

Źródło: Strupczewski, 2015, s. 4-95.

W kosztach ujęto koszt emisji $\mathrm{CO}_{2}$ zalecany przez projekt NewExt. Koszty emisji NOx zawierają skutki wyrządzone przez azotany (cząstki wtórne), ozon, depozycja azotu działająca jako nawóz oraz skutki związków kwaśnych. NMVOC (niemetalowe lotne związki organiczne) biorą udział w tworzeniu smogu ozonowego (fotochemicznego), dwutlenek siarki ( $\left.\mathrm{SO}_{2}\right)$ oddziałują tu cząstki wtórne (aerozole siarczanów) tworzą kwas siarkowy i aerozole siarczanów, pyły zawieszone PM2,5-10 - związki organiczne mające szczególne znaczenie w powstawaniu smogu ozonowego.

Koszty zewnętrzne w energetyce zawodowej w Polsce na jednostkę energii elektrycznej przedstawia tabela 3. Obliczono je na podstawie średnich wartości kosztów zewnętrznych przypadających na tonę emisji oraz uwzględniono dane statystyczne dotyczące wielkości emisji i wielkości wyprodukowanej energii elektrycznej w Pol- 
sce. Na podstawie danych uśredniony koszt zewnętrzny bez uwzględnienia emisji dwutlenku węgla obliczony dla jednego megawata energii elektrycznej w Polsce w latach 2007-2008 wynosił ok. 35,42 euro. Przy średnim koszcie zewnętrznym bez emisji $\mathrm{CO}_{2}$ w wysokości $7767 € / \mathrm{t} \mathrm{SO}_{2}$ koszt zewnętrzny energii elektrycznej w Polsce wynosił ok. $35 € / \mathrm{kWh}$ (Uros, 2015, s. 4-95). Biorąc pod uwagę emisję dwutlenku węgla, ten koszt zwiększa się o kolejne 22 euro.

Tabela 3. Jednostkowe koszty zewnętrzne wytwarzania energii elektrycznej w energetyce zawodowej w Polsce (€/MWh)

\begin{tabular}{|l|c|c|c|c|}
\hline & $\begin{array}{c}\text { Elektrownie na węgiel } \\
\text { brunatny }\end{array}$ & $\begin{array}{c}\text { Elektrownie na węgiel } \\
\text { kamienny }\end{array}$ & Elektrociepłownie & $\begin{array}{c}\text { Ogółem } \\
\text { elektrownie }\end{array}$ \\
\hline $\mathrm{SO}_{2}$ & 31,94 & 18,52 & 28,32 & 25,10 \\
\hline $\mathrm{NOx}$ & 8,45 & 10,08 & 9,82 & 9,43 \\
\hline $\mathrm{PM} 2,5-10$ & 0,10 & 0,06 & 0,11 & 0,08 \\
\hline PM 2,5 & 0,60 & 0,67 & 1,35 & 0,75 \\
\hline NMVOC & 0,05 & 0,07 & 0,04 & 0,05 \\
\hline Razem: & 41,13 & 29,42 & 39,65 & 35,42 \\
\hline $\mathrm{CO}_{2}$ & 24,60 & 20,25 & 21,45 & 22,07 \\
\hline Łącznie: & 65,73 & 49,67 & 61,10 & 57,50 \\
\hline
\end{tabular}

Źródło: Radoviĉ, 2009, s. 16.

Rodzaj stosowanych technologii energetycznych powiązany jest nieodzownie z negatywnym oddziaływaniem, a przede wszystkim z emisjami zanieczyszczeń. Stosowanie technologii mniej emisyjnej pozwala zachować nie tylko standardy emisyjności, ale i niższe koszty negatywnego oddziaływania. Koszty zewnętrzne wybranych instalacji energetycznych według programu NEEDS obliczone dla wszystkich krajów prezentuje tabela 4. Uwzględniono tu koszty zewnętrzne w całym łańcuchu budowy, eksploatacji i zamknięcia źródła wytwórczego. Różnice kosztów zewnętrznych prezentowanych technologii różnią sie zdecydowanie i są odzwierciedleniem stosowanych rozwiązań technologicznych. W zależności od stosowanej technologii mamy systemy energetyczne o wysokiej emisyjności, do których należą elektrownie wodorowe, elektrownie węgla brunatnego, węgla kamiennego i systemy o niskiej emisyjności, można do nich przede wszystkim zaliczyć elektrownie wiatrowe, jądrowe, fotowoltaikę i elektrownie na gaz z systemem oczyszczania zanieczyszczeń. 
Tabela 4. Koszty zewnętrzne różnych źródeł energetycznych (€centy/kWh)

\begin{tabular}{|c|c|c|c|c|c|c|c|}
\hline & 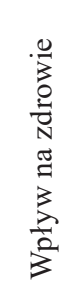 & 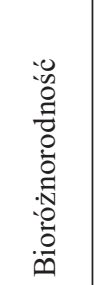 & 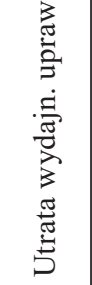 & 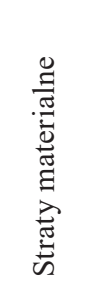 & 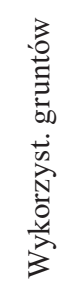 & 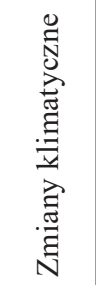 & 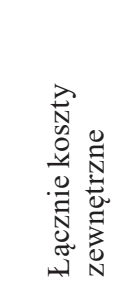 \\
\hline elektrownia węgla brunatnego $900 \mathrm{MW}$ & 0,72 & 0,07 & 0,02 & 0,01 & 0,01 & 2,016 & 2,99 \\
\hline $\begin{array}{l}\text { elektrownia węgla brunatnego } \\
\text { z oczyszczaniem zanieczyszczeń }\end{array}$ & 0,95 & 0,16 & 0,03 & 0,01 & 0,02 & 0,40 & 1,57 \\
\hline elektrownia węgla kamiennego $600 \mathrm{MW}$ & 1,00 & 0,08 & 0,03 & 0,02 & 0,05 & 2,26 & 3,44 \\
\hline $\begin{array}{l}\text { elektrownia węgla kamiennego } \\
\text { z oczyszczaniem zanieczyszczeń }\end{array}$ & 1,15 & 0,17 & 0,03 & 0,02 & 0,06 & 0,41 & 1,84 \\
\hline elektrociepłownia na gaz ziemny & 0,24 & 0,02 & 0,01 & 0,01 & 0,01 & 1,17 & 1,46 \\
\hline komórki paliwowe drewno-gaz & 0,56 & 0,06 & 0,02 & 0,01 & - & 0,15 & 0,80 \\
\hline elektrownie wiatrowe & 0,06 & 0,00 & 0,00 & 0,00 & - & 0,02 & $0,06-0,08$ \\
\hline elektrownia fotowoltaiczna & 0,47 & 0,02 & 0,00 & 0,01 & - & 0,03 & $0,1-0,63$ \\
\hline elektrownia na biomasę & 1,53 & 0,09 & 0,06 & 0,03 & 0,66 & 0,04 & $0,07-2,51$ \\
\hline elektrownia jądrowa & 0,06 & 0,004 & 0,001 & 0,001 & 0,01 & 0,01 & 0,09 \\
\hline wodór & 3,82 & 0,22 & 0,04 & 0,10 & 0,06 & 2,01 & 6,25 \\
\hline
\end{tabular}

Źródło: opracowanie własne na podstawie International Renewable Energy Agency, 2018, s. 17.

\section{Efekt ekologiczny elektrowni wiatrowych}

Szkody ekologiczne powstałe w związku z energią konwencjonalną utożsamia się z kosztami zewnętrznymi obciążającymi jednostkę wytwarzania energii. Wytwarzanie energii ze źródeł odnawialnych również wykazuje emisję zanieczyszczeń i związane z tym koszty zewnętrzne, jednak są one zdecydowanie niższe.

Efekt ekologiczny wykorzystania energii z wiatru przedstawia formuła (Solińska, Soliński, 2003, s. 82-85):

$$
\mathrm{EOi}=\mathrm{KZW}-\mathrm{KZOi}
$$

gdzie:

EOi - efekt ekologiczny wykorzystania energii odnawialnej z i-tego źródła OZE;

KZW - koszt zewnętrzny obciążający energię wytworzoną z węgla;

KZOi - koszt zewnętrzny obciążający energię wytworzoną z i-tego źródła OZE. 
Dla obliczeń założono, że ocena efektu ekologicznego dotyczyć będzie fazy eksploatacji źródeł. Dla obliczenia efektu ekologicznego elektrowni wiatrowych przypisana zostanie wielkość emisji unikniętych w wyniku wprowadzenia energii z wiatru. Obliczono efekt ekologiczny dla każdego roku oddzielnie na podstawie ilości wyeliminowanej energii z węgla oraz przyjętych do obliczeń wskaźników emisyjnych przypisanych dla energii z węgla. Do obliczeń przyjęto wartości wskaźników ustanowione w programie NEEDS.

Jednostkowe koszty zewnętrzne ustanowione przez program NEEDS:

- dla energii z węgla - 2,99 euro/kwh,

- dla elektrowni wiatrowych - 0,08 euro/kWh.

Efekt ekologiczny wykorzystania energii z wiatru: $\mathrm{EOi}=2,99-0,08=2,91 \mathrm{euro} /$ $\mathrm{kWh}$.

To wielkość unikniętej emisji, wynikająca z zastąpienia energii z węgla energią z wiatru. Wielkość kosztów zewnętrznych obciążających energetykę zawodową jest o 3537,5\% większa niż koszty zewnętrzne energetyki wiatrowej. Wielkość efektu ekologicznego jest znacząca i wynosi na jednostkę 2,91 euro/kWh.

Chcąc oszacować wartość wymiernego efektu ekologicznego energii z wiatru na podstawie udziału produkcji energii elektrycznej z elektrowni wiatrowych w krajowej produkcji energii w energetyce zawodowej w latach 2005-2016, dokonano obliczeń i zawarto je w tabeli 4. W związku z tym, że dane użyte do obliczeń mają bardzo duże wielkości w pierwszej kolejności dokonano zamiany jednostek z wartości euro/kWh na mld euro/GWh.

Koszty zewnętrzne obciążające energetykę zawodową to 2,99 euro/kWh $\rightarrow$ 2990000 euro/GWh, koszty zewnętrzne obciążające energetykę wiatrową to 0,08 euro/kWh $\rightarrow 80.000$ euro/GWh. Wykazano produkcję energii z węgla w poszczególnych latach, dokonując obliczeń całkowitego kosztu zewnętrznego obciążającego energię z węgla za dany rok. Krajowa produkcja energii elektrycznej z węgla wykazuje coroczny wzrost, wzrasta również jej całkowity koszt zewnętrzny. Całkowity koszt zewnętrzny energii z węgla przez cały okres badawczy utrzymuje się na bardzo wysokim poziomie. Najwyższą jego wartość odnotowano w 2006 roku (435,27 mld euro), a najniższą w 2014 roku (374,51 mld euro). W 2010 roku zauważyć można obniżenie się produkcji energii z węgla o ok. 10\% w stosunku do 2005 roku; jest ona wynikiem zwiększającego się udziału energii odnawialnej w krajowej produkcji energii. Przeanalizowano również wielkości całkowitych kosztów zewnętrz- 
nych obciążających energię wiatrową. Najwyższą wartość kosztów zewnętrznych wykazano w 2015 roku (0,72 mld euro), a najniższą wartość kosztów zewnętrznych odnotowano w 2005 roku ( 0,01 mld euro).

Tabela 4. Efekt ekologiczny wykorzystania energii z wiatru na podstawie krajowej produkcji energii elektrycznej w latach 2005-2016 (mld euro/GWh)

\begin{tabular}{|c|c|c|c|c|c|}
\hline lata & $\begin{array}{c}\text { Produkcja } \\
\text { energii } \\
\text { z węgla }\end{array}$ & $\begin{array}{c}\text { Koszt zewnętrzny } \\
\text { obciążający energię } \\
\text { z węgla }\end{array}$ & $\begin{array}{c}\text { Produkcja } \\
\text { energii } \\
\text { z wiatru }\end{array}$ & $\begin{array}{c}\text { Koszt zewnętrzny } \\
\text { obciążający energię } \\
\text { z wiatru }\end{array}$ & $\begin{array}{c}\text { Efekt } \\
\text { ekologiczny }\end{array}$ \\
\hline 2005 & 141250 & 422,34 & 135,5 & 0,01 & 422,33 \\
\hline 2006 & 145575 & 435,27 & 256,1 & 0,02 & 435,25 \\
\hline 2007 & 143425 & 428,84 & 521,6 & 0,042 & 428,80 \\
\hline 2008 & 139775 & 417,93 & 836,8 & 0,067 & 417,86 \\
\hline 2009 & 136550 & 408,28 & 1077,3 & 0,086 & 408,19 \\
\hline 2010 & 126133 & 377,14 & 1664,3 & 0,133 & 377,00 \\
\hline 2011 & 130844 & 391,22 & 3204,5 & 0,256 & 390,94 \\
\hline 2012 & 129711 & 387,84 & 4747 & 0,38 & 387,46 \\
\hline 2013 & 130001 & 388,70 & 6004 & 0,48 & 388,22 \\
\hline 2014 & 125254 & 374,51 & 7676 & 0,61 & 373,9 \\
\hline 2015 & 129378 & 386,84 & 10707 & 0,86 & 385,98 \\
\hline 2016 & 130101 & 389,00 & 12491 & 1,0 & 385,84 \\
\hline
\end{tabular}

Źródło: obliczenia własne na podstawie danych GUS.

Wynikiem najwyższych kosztów zewnętrznych obciążających energię z wiatru jest najwyższa odnotowana produkcja energii z elektrowni wiatrowych, najniższy całkowity koszt zewnętrzny jest wynikiem bardzo niskiego udziału energii z wiatru w całkowitej produkcji energii w Polsce. Wykazany efekt ekologiczny wykorzystania energii wiatrowej stanowi różnicę między całkowitym kosztem obciążającym energię z węgla a całkowitym kosztem obciążającym energię z wiatru. Są to relatywnie bardzo duże kwoty. W roku 2005 efekt ekologiczny wynosił 422,33 mld euro. W 2006 roku wykazano najwyższą wartość tych kosztów, które wzrosły o ok. 3,06\% w stosunku do 2005 roku. W 2007 roku koszt ekologiczny wyniósł 428,8 mld euro. Wzrósł on o ok. 1,53\% w porównaniu do roku 2005. W 2008 roku koszt ekologiczny obniżył się o ok. 1,06 \% w stosunku do 2005 roku i wynosił 417,86 mld euro. W roku 2009 poziom efektu ekologicznego to 408,19 mld euro i w stosunku do 2005 roku obniżył się o ok. 3,35\%. W 2010 roku odnotowano wzrost efektu ekologicznego w stosunku do roku poprzedniego, jednak w stosunku do 2005 roku 
odnotowano jego spadek o ok. 10,7\%, efekt wynosił 377,0 mld euro. 2011 rok to zdecydowany wzrost produkcji energii z wiatru i związany z tym wzrost efektu ekologicznego, chociaż do 2005 roku odnotowano spadek o ok. 7,4\%. Jego wartość to 390,94 mld euro. W 2012 roku nastąpił nieznaczny spadek produkcji energii z węgla, stąd równocześnie zaobserwowano spadek efektu ekologicznego (wynosi 387,46 mld euro). W 2013 roku nadal odnotowuje się wzrost efektu ekologicznego. Rok 2014 to okres, w którym najniższy poziom efektu ekologicznego w stosunku do analizowanego okresu wynosi 373,9 mld euro. W roku 2015 odnotowano efekt ekologiczny na poziomie 385,98 mld euro. W ostatnim analizowanym 2016 roku odnotowano wzrost produkcji energii z węgla i wiatru, otrzymano efekt ekologiczny w wysokości 385,84 mld euro.

Dla dodatkowego zobrazowania wymiaru kosztów zewnętrznych obciążających energię elektryczną wytwarzaną w konwencjonalny sposób, przedstawiono porównanie tych kosztów do ceny sprzedaży energii elektrycznej. W 2016 roku średnioważona wolumenem cena transakcyjna ukształtowała się na poziomie 159,26 zł/ MWh (zob. URE, 2016), a koszt zewnętrzny przypadający na 1 MWh wytworzonej energii z węgla to 2290 euro/MWh.

\section{Podsumowanie}

Wykazany efekt ekologiczny energii z wiatru na podstawie udziału produkcji energii elektrycznej z elektrowni wiatrowych w krajowej produkcji energii w energetyce zawodowej w Polsce dowodzi, że są to ogromne koszty, które statystyczny Polak ponosi, choć nie ma o nich wiedzy, wykazany efekt ekologiczny to miliony euro, a biliardy złotych. Niniejszy artykuł dowodzi, że energia z wiatru niezbędna jest dla prawidłowego funkcjonowania gospodarki, a głównie dla zdrowego życia i poszanowania środowiska. Dokonując analizy korzyści ekologicznych, wykazano, że energia $\mathrm{z}$ wiatru niezbędna jest dla osiągnięcia określonych efektów ekologicznych. Wdrażanie energii z wiatru zdecydowanie ogranicza wielkości emisji substancji zanieczyszczających oraz przyczynia się do wymiernych efektów ekologicznych. Zaprezentowany wymierny efekt ekologiczny pozwala uzmysłowić sobie skalę problemu emisji zanieczyszczeń. W dłuższej perspektywie czasu na wdrażaniu ekologicznych rozwiązań społeczeństwo naszego kraju może tylko zyskać. 


\section{Bibliografia}

Dones, R. i in. (2005). ExternE-Pol Externalities of Energy: Extension of Accounting Framework and Policy Applications (Contract $N^{\circ}$ ENG1-CT-2002-00609). Final Report on Work Package 6: New Energy Technologies. Pobrane z: http://www.externe.info/externe_2006/expolwp6.pdf (19.11.2018).

ExterneE (2003). External Costs. Research results on socio-environmental damages due to electricity and transport. Community Research, European Commission DirectorateGeneral for Research Information and Communication, Brussels. Pobrane z: http://www. externe.info/externe_2006/externpr.pdf (12.12.2018).

Famielec, J. (red.) (2001). Straty gospodarcze spowodowane zanieczyszczeniem środowiska naturalnego $w$ Polsce $w$ warunkach transformacji gospodarczej-część pierwsza. Kraków: Wydawnictwo Akademii Ekonomicznej w Krakowie.

IRENA (2018). Renewable Power Generation Costs in 2017. Abu Dhabi: International Renewable Energy Agency.

Kudełko, M. (2003). Koszty zewnętrzne systemów energetycznych. Polityka Energetyczna, 6 [spec. 2], 91-105. New Energy Externalities Developments for Sustainability (2009). External costs from emerging electricity generation Technologies, Deliverable n 6.1-RS1a.

Preiss, P., Friedrich, R., Klotz, V. (2008). Report on the procedure and data to generate aver -aged/aggregated data, including ExternalCosts_per_unit_emission. [b.m.w.].

Radoviĉ, U. (2009). Porównanie wpływu na zdrowie człowieka i środowisko naturalne różnych źródet energii - wyniki badań w programie ExternE. Warszawa: Agencja Rynku Energii SA.

Solińska, M., Soliński, I. (2003). Efektywność ekonomiczna proekologicznych inwestycji rozwojowych w energetyce odnawialnej. Kraków: Uczelniane Wydawnictwa NaukowoDydaktyczne Akademii Górniczo-Hutniczej.

Strupczewski, A. (2015). Analiza i ocean kosztów energii elektrycznej z różnych źródel energii w Polsce. Świerk-Otwock: Narodowe Centrum Badań Jądrowych.

Sundqvist, T., Sodernholm, P. (2003). Valuing the Environmental Impacts of Electricity Generation: A Critical Survey. Austria.

URE (2016). Urząd Regulacji Energetyki. Charakterystyka rynku energii elektrycznej. Pobrane z: https://www.ure.gov.pl/pl/rynki-energii/energia-elektryczna/charakterystyka -rynku/7040,2016.html (8.06.2018). 


\title{
THE ANALYSIS OF ECOLOGICAL BENEFITS OF WIND POWER INDUSTRY IN POLAND
}

\begin{abstract}
The article presents ecological benefits resulting from the implementation of electricity generated by wind power plants. The Authors pay attention to the links between renewable energy, the issue of environmental protection and the electricity market. The paper presents the output size of conventional and renewable energy in Poland in the years 2005-2016. Moreover, the influence of the energy sector on the environment and human health is described. The analysis shows that wind power is an indispensable source of electricity allowing to avoid millions of dollars worth of external costs.
\end{abstract}

Translated by Magdalena Montwit

Keywords: commercial power industry, wind energy, ecological benefits

Kod JEL: O13 